\title{
A Study on Herpes Simplex Encephalitis in 18 Children, Including 3 Relapses
}

\author{
Mustafa A. M. Salih", , Heba Y. El Khashab ${ }^{1}$, Hamdy H. Hassan², Amal Y. Kentab ${ }^{1}$, Sara S. Al Subaei ${ }^{3}$, \\ Radwan M. Zeidan ${ }^{4}$, Mohammed N. Al-Nasser ${ }^{1}$ and Saleh A. Othman ${ }^{5}$
}

\author{
${ }^{I}$ Division of Pediatric Neurology, Department of Pediatrics, College of Medicine, King Saud University, Riyadh, Saudi \\ Arabia \\ ${ }^{2}$ Department of Radiology, College of Medicine, King Saud University, Riyadh, Saudi Arabia \\ ${ }^{3}$ Division of Infectious Diseases, Department of Pediatrics, College of Medicine, King Saud University, Riyadh, Saudi \\ Arabia \\ ${ }^{4}$ Division of Neurology, College of Medicine, King Saud University, Riyadh, Saudi Arabia \\ ${ }^{5}$ Nuclear Medicine Department, College of Medicine, King Saud University, Riyadh, Saudi Arabia
}

\begin{abstract}
Background: Herpes Simplex Virus (HSV) is the most common cause of acute sporadic focal encephalitis. Early Diagnosis is, therefore, crucial for predicting outcome. Improved laboratory technology and improved neuroimaging accessibility have enhanced our ability to diagnose this condition.

Aims: To assess the reliability of different investigative tools in diagnosing and subsequent management of herpes simplex encephalitis (HSE); as well as the impact of infection and its relapse on the outcome of a cohort of 18 children evaluated during a period of 13 years.
\end{abstract}

Methods: This combined prospective and retrospective study describes the clinical, laboratory, electroencephalographic and diagnostic imaging studies; and outcome in a cohort of 18 children with HSE over a period of 13 years. It also details the clinical and diagnostic features of 3 patients who relapsed.

Results: The commonest initial presenting symptoms and signs were fever (100\%), seizures (72\%) irritability (50\%) and weakness/hemiparesis (39\%). Cerebrospinal fluid (CSF) pleocytosis was found in $62 \%$, red blood cells $(\mathrm{RBCs})>10 \times 10^{6} / \mathrm{L}$ in $81 \%$ and raised proteins $(>0.59 \mathrm{~g} / \mathrm{L})$ in $52 \%$. Examination for herpes simplex virus (HSV) by polymerase chain reaction (PCR) was positive in 50\% (6/12). Electroencephalographic changes were universally abnormal $(17 / 17 ; 100 \%)$ and periodic lateralization discharges (PLEDS) were seen in 35\% (6/17). During the acute stage (days 1-8 from symptom onset), magnetic resonance imaging (MRI) revealed abnormalities in 91\% (10/11), cranial computed tomography (CT) in $50 \%(5 / 10)$ and single photon emission computed tomography (SPECT), within $\leq 7$ days, in 75\% (6/8). All patients were treated with intravenous acyclovir. There were no deaths but 3 patients relapsed after periods ranging between 18 days and 66 months. Eleven (61\%) patients had no or minor sequelae (good outcome) and 7 (39\%) had moderate or severe sequelae (poor outcome). Delayed initiation of therapy ( $>3$ days from onset of symptoms) had significant association with poor outcome $(\mathrm{P}=0.002)$. Initial negative $\mathrm{PCR}$ results may become positive on subsequent CSF specimen.

Conclusion: Diagnosis of HSE requires combined clinical, laboratory, electroencephalographic and neuroimaging studies. Negative results of PCR do not exclude the infection and should not interrupt the treatment. Early diagnosis and initiation of treatment minimize the devastating effect of HSE. Full course treatment with acyclovir for 21 days is also crucial for prognosis and prevention of subsequent relapse.

Keywords: Herpes simplex virus, encephalitis, children, relapse, outcome, PCR, EEG, CT, MRI, SPECT brain scan.

\section{INTRODUCTION}

Herpes simplex encephalitis (HSE) is a devastating central nervous system (CNS) infection with an estimated incidence of about 1 in 250,000 to 500,000 people per year and a third of cases occurring in children [1]. The mortality rate of untreated HSE in $70 \%$ in adults, and $23 \%$ of patients

*Address correspondence to this author at the Department of Pediatrics, Division of Pediatric Neurology, College of Medicine, P.O. Box 2925, King Saud University, Riyadh 11461, Saudi Arabia;

E-mail: mustafa_salih05@yahoo.com are able to return back to normal function [2]. A dramatic improvement of the survival rate and prognosis occurs if treatment is initiated very early after the onset of the disease [2-4]. Early diagnosis is, therefore, crucial for predicting the outcome [3].

Detection of herpes simplex virus (HSV) in the cerebrospinal fluid (CSF) through polymerase chain reaction (PCR) is the diagnostic modality of choice for HSE [5]. However, negative results for PCR are reported in both adults [6] and children [3, 7-12]. Therefore, recognition of imaging patterns of HSE is imperative [13]. Magnetic 
resonance imaging (MRI) reveals a disease in T1 signal and increased T2 signal in the medial temporal lobes and insulae, and in the orbital frontal lobes with abnormalities appearing earlier and more frequently than with brain computed tomography (CT) of the brain [14]. Recently, diffusionweighted imaging (DWI) was found to play a major role as a first and early diagnostic step [15], especially within the first 72 hours of infection when CSF might be negative for HSV DNA using PCR technique [16].

Other diagnostic studies for patients with presumed HSE include electroencephalography (EEG) which reveals focal abnormalities in about $80 \%$ of cases [17]. In some patients, widespread periodic lateralized epileptiform discharges (PLEDs) are seen [18]. Focal unilateral hyperperfusion, as visualized by single photon emission computed tomography (SPECT) brain scans, has also been proposed as a sensitive indicator of severe inflammation of the brain tissue in HSE [19]. It can also help in differentiating HSV infection from other ischemic, tumoral or demyelinating processes [20].

The present study describes the clinical, laboratory, electroencephalographic and diagnostic imaging studies; and outcome in a cohort of 18 children with HSE seen at our institution over a period of 13 years. It also details the clinical and diagnostic features of 3 patients who relapsed.

\section{PATIENTS AND METHODS}

The study included children with suspected HSE, who were evaluated at the Division of Paediatric Neurology (DPN), or were inpatients in the paediatric wards at King Khalid University Hospital (KKUH), Riyadh, Saudi Arabia. As stipulated in its design, the study covered 13 years and had 2 components as follows:

Retrospective Study: This included 12 patients. All the case records of children who were evaluated at the DPN or admitted to KKUH with clinical features suggestive of HSE during the period June 1993 to May 2001 (8 years) were reviewed. The diagnosis of HSE was considered to be accepted when supported by the clinical and other ancillary findings. The latter included biological (CSF analyses, including HSV PCR in some cases), radiological (CT and/or $\mathrm{MRI}$, electrophysiological (EEG) and nuclear (SPECT) investigations. Relevant information about each child was retrieved. This included age at onset of HSE, sex, clinical symptoms and signs, laboratory findings at presentation, EEG results, CNS imaging studies, hospital course, treatments and outcome. The time delay between the onset of symptoms and the date of admission, diagnosis and initiation of treatment as well as the dose and duration of acyclovir therapy were recorded.

Prospective Study: This included 6 patients seen between June 2001 and May 2006 (5 years). This group of patients were subjected to detailed history taking and thorough clinical examination, CSF, HSV DNA PCR, EEG studies, neuroimaging including either cranial CT scan, MRI or both and SPECT brain studies. Patients were treated with acyclovir for 21 days and were followed strictly for outcome.

The outcome of the disease was defined according to the National Institute of Allergy and Infectious Diseases Collaborative Antiviral Study Group [21] as follows: (1) Normal; (2) Mild sequelae (with minor neuropsychological deficits); (3) Moderate sequelae (with limitations to motor, speech, memory or seizure disorders) and (4) Severe sequelae (requirements for supporting care or death). Patients with normal and mild sequelae were classified as having good outcome and those with moderate and severe sequelae as having poor outcome.

Methods: The facility of MRI, performed at $1.5 \mathrm{~T}$, became available at KKUH in May 1999. Before that, arrangements were made for this imaging modality at King Fahad National Guard Hospital, King Abdulaziz Medical City, Riyadh. The program for diffusion-weighted images was introduced in 2003. Electroencephalography was performed using traditional 21 leads. Technitium SPECT brain scans were used to depict cerebral perfusion using either technetium-99m-hexamethylpropyleneamine oxime $\left({ }^{99 \mathrm{~m}} \mathrm{Tc}-\mathrm{HMPAO}\right)$ or technetium-99m-ethylcysteinate dimer $\left({ }^{99 \mathrm{~m}} \mathrm{Tc}-\mathrm{ECD}\right)$. In some patients blood brain barrier (BBB) breakdown was explored using technetium-99mdiethylenetriaminepentaacetic acid ( ${ }^{99 \mathrm{~m}}$ Tc-DTPA).

During the period 1997-2003, PCR amplification assays for the detection of HSV DNA in CSF were performed at a collaborating laboratory in Riyadh (King Faisal Specialist Hospital and Research Centre). As of 2004, real-time PCR assay became available at KKUH.

Statistical Analysis: The Stat Pac Gold Statistical Analysis Package was used for data management. Fisher's exact test was used for comparison of data among the different groups. A probability value of $<0.05$ was considered to be significant.

\section{RESULTS}

During the combined study period of 13 years, 18 Saudi patients with confirmed diagnosis of HSE were evaluated. They consisted of 9 males and 9 females, including two female siblings. Patients were aged from 3 months to 10 years with mean age of $(3.2 \mathrm{y} \pm 2.9 \mathrm{y})$ and median 2 years. Among these, 5 patients (28\%) were aged 3-12 months, 9 $(50 \%)$ were 1 to 4 years of age and 4 patients $(22 \%)$ were aged 5-10 years. Three out of the 18 patients got relapse of herpetic encephalitis later on during the study period at a mean age of $(4.6 y \pm 3 y)$ and median of 6 years. All 18 patients presented with fever (Table 1). Irritability (in 50\%) and drowsiness (in 33\%) were remarkable symptoms in all age groups, while headache mainly manifested in patients $>$ 4 years $(100 \%)$. Thirteen $(72 \%)$ patients presented with focal seizures, $7(39 \%)$ with hemiparesis, one $(5.5 \%)$ patient presented with aphasia and another one $(5.5 \%)$ with squint.

During the study period, 21 CSF samples were drawn from the patients within the first 5 days of illness. Analysis of CSF showed elevated white blood cell (WBC) count $\left(>10 \times 10^{6} \mathrm{~L}\right)$ in $13(62 \%)$, red blood cells (RBCs) count $>10 \times 10^{6} \mathrm{~L}$ in $17(81 \%)$ and raised proteins $(>0.59 \mathrm{~g} / \mathrm{l})$ in 11 (52\%) samples. Examination for HSV by PCR in $12(57 \%)$ of these $21 \mathrm{CSF}$ specimens revealed positive results in 6 $(50 \%)$. A statistical analysis revealed no significant associated between positive results of PCR and either the presence in the CSF of elevated WBC count $\left(>10 \times 10^{6} / \mathrm{L}\right)$, RBCs $\left(10 \times 10^{6} / \mathrm{L}\right)$ or proteins $(>0.59 \mathrm{~g} / \mathrm{L})$. Repeated lumbar puncture was done for 5 patients during their course of their illness, and PCR was performed in 3 of them revealing a positive result in one patient on day 8 after onset of 
symptoms. The first CSF sample of this child, taken on day 3 of his illness, was negative for HSV by PCR.

Serological testing for HSV was done for 11 (61\%) patients during the acute stage (within the first 5 days of illness). No serological tests were attempted at convalescence. Both anti-HSV IgG and IgM antibodies were positive in $3(27 \%)$ of the 11 acute sera, whereas a fourth sample was positive for anti-HSV IgG antibodies only. Simultaneous CSF analysis for HSV PCR was done within the first 5 days of illness in 6 of these 11 patients and it revealed positive results in $2(33 \%)$. There was no statistically significant association between positive PCR results for $\mathrm{HSV}$ in CSF and detection of anti-HSV IgM antibodies in acute sera.

Serial cranial CT scans revealed unilateral or bilateral hypodensity in the temporal lobes with, or without, involvement of other areas (frontal, parietal or occipital) in 8 (57\%) of 14 patients. In $2(14 \%)$ patients the abnormalities were confined to either frontal or occipitopariental lobes. Out of these 10 patients, the initial CT scan, done on days 18 from onset of symptoms, was normal in $5(50 \%)$. Hyperdense lesions of hemorrhage were observed in $6(60 \%)$ patients. Follow-up CT brain scan in the chronic stage of the disease, done for 3 patients, revealed encephalomalacia and brain atrophy.

On MRI, done during the acute stage, hyperintense signal (on T2-weighted images) and/or restricted diffusion abnormalities (on diffusion-weighted images) were seen in $10(91 \%)$ of 11 patients. These corresponded to oedematous changes in the temporal lobes in $8(73 \%)$, while in $2(18 \%)$ patients localization was either to frontal lobe or parietooccipital region. Only one of $11(9 \%)$ MRI scans revealed no abnormality. This has been performed 4 days after symptom onset. In this patient, examination of CSF (taken on day 5 from onset of symptoms) revealed positive PCR for HSV. Subacute hemorrhagic lesions, as revealed by high sign intensities on T1- MRI images, were detected in 2 patients. In a 6-month-old boy with HSE, the initial CT (done on day 5 after the onset of symptoms) showed bilateral hypodensity in the temporal lobes. Cranial MRI done 12 days later, showed the temporal lesions, as well as subacute hemorrhage at the pons (Fig. 1). Both lesions showed remarkable resolution on a follow-up MRI done about 18 months later.

Seventeen (94\%) of 18 children had EEG assessment, and abnormalities were present in all of them. These consisted of non-specific diffuse slow waves in $4(24 \%)$ patients and focal slow waves in $13(76 \%)$. Slowing was restricted to the temporal area in 7(41\%) while 6(35\%) patients displayed typical PLEDs. However, there has been no significant association between the presence of PLEDs on EEG and a positive PCR result for HSV in the CSF (P = $0.64)$.

Fourteen $(78 \%)$ of the 18 patients had a total of 18 SPECT brain scans. Of these scans, $14(78 \%)$ were during admission with acute HSE within a period ranging between 2 and 19 days after the onset of symptoms (mean $[+\mathrm{SD}]=9.3$ \pm 5.77 days, median $=7$ days). The rest $(12 \%)$ were done after the infection has resolved within a period ranging between 8 months and 3 years. The radiopharmaceuticals used during the acute stage were ${ }^{99 \mathrm{~m}} \mathrm{Tc}-\mathrm{HMPAO}$ in $8(57 \%)$, ${ }^{99 \mathrm{~m}} \mathrm{Tc}-\mathrm{DTPA}$ in $5(36 \%)$ and ${ }^{99 \mathrm{~m}} \mathrm{Tc}-\mathrm{EDC}$ in one (7\%) SPECT examinations. Neither the ${ }^{99 \mathrm{~m}}$ Tc-HMPAO nor the ${ }^{99 \mathrm{~m}} \mathrm{Tc}-$ DTPA showed increased uptake after the $7^{\text {th }}$ day from the onset of symptoms. The third radiopharmaceutical $\left({ }^{99 \mathrm{~m}} \mathrm{Tc}-\right.$ EDC) was used in one patient with hemorrhagic HSE who had SPECT brain scan at 12 days from onset of symptoms. Of the 4 SPECT scans which were done within a period of $\leq$ 7 days using ${ }^{99 \mathrm{~m}} \mathrm{Tc}-\mathrm{HMPAO}, 3(75 \%)$ showed increased perfusion and the fourth revealed decreased perfusion. Likewise, using ${ }^{99 \mathrm{~m}} \mathrm{Tc}$-DTPA three (75\%) of the four SPECT scans showed evidence of BBB breakdown and increased uptake, whereas the fourth patient had decreased uptake. The 4 patients with evidence of BBB breakdown included a 10month-old boy who had hemorrhagic HSE (Fig. 2). Carotid angiography in this patient (done to rule out a suspected arteriovenous malformation) showed no evidence of vascular anomaly.

The clinical features and investigation results of the 3 children who had relapsing HSE are shown in Tables $\mathbf{2}$ and 3. During the initial infection (Table 2), their ages were 2 years, 20 months and 4 years, respectively. Relapses occurred after periods ranging between 18 days and 66 months. None of them was immune-compromised. Neurological manifestations of the relapses (Table 3) were drowsiness, or decreased level of consciousness, and hemiparesis in two patients associated with abducent nerve palsy in one of them. Patient 2 (Table 3) had choreoform movements two weeks after admission with relapse and starting acyclovir therapy. Patient 1 (Table 2), who had acyclovir for 10 days, relapsed 18 days after the initial HSE and presented with choreoform movements (Table 3). In the three patients, relapse was best detected by MRI which showed sequelae of old infection and also signs of recent infection on diffusion-weighted images and/or T2-weighted images (Fig. 3). Signs of inflammatory changes were in the same site of the disease in Patient 2 (Fig. 3), while it extended to the contralateral side in the other two patients. Of note is that the relapse in Patient 2 was associated with lip vesicular lesions. A swab from these revealed positive immunofluorescence for HSV type 1 (Fig. 3). It's also noteworthy that Patient 2 was admitted with his initial infection to KKUH 40 days after onset of symptoms (Table 2). He had interrupted acyclovir therapy at another 2 hospitals since his parents took him against medical advice looking for other medical opinions. Analysis of CSF on admission revealed negative results for HSV PCR. Four days after start of acyclovir, his fever relapsed again. Brain MRI (done 2 days later) showed bifrontal cystic encephalomalacia associated with diffused white matter attenuation (Fig. 3A).

There were no deaths in this cohort of 18 patients, 10 (56\%) had no sequelae of HSE, whereas one $(6 \%)$ patient had minor sequelae in the form of minor neuropsychological deficits. Two (11\%) patients had moderate sequelae in the form of easily controlled seizures or attention deficit hyperactivity disorder. Severe sequelae were seen in $5(28 \%)$ patients. These consisted of residual cerebral palsy, intractable seizures and/or mental retardation requiring 

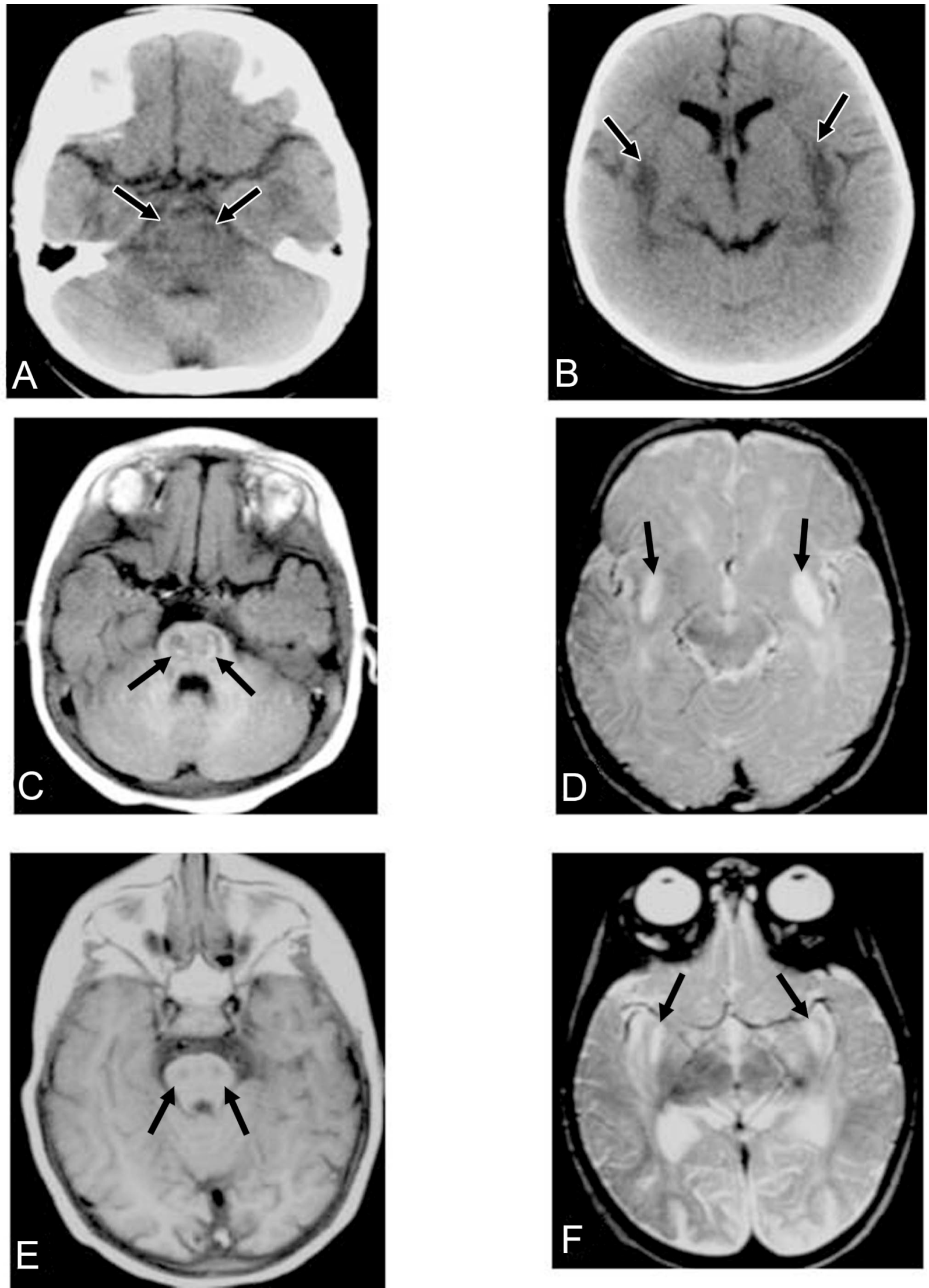

Fig. (1). (A \& B) Axial CT study dated $2^{\text {nd }}$ June 1993, showing small hypodense lesions on both sides of the pons (arrows in A) and hypodense lesions at temporal lobes (arrows in B). (C) Axial SE T1-weighted MRI, study dated $14^{\text {th }}$ June 1993, shows high signal intensity (arrows) on the pons indicating subacute hemorrhagic lesions and (D) Axial T2 MRI on the same date, shows high signal lesions at temporal lobes (arrows). (E) Axial SE T1-weighted MRI, study dated $30^{\text {th }}$ Jan. 1995, shows small resolving low signal lesions at the pons (arrows) and (F) Axial T2-weighted MRI on the same date, shows smaller resolving high signal lesions at temporal lobes (arrows). 


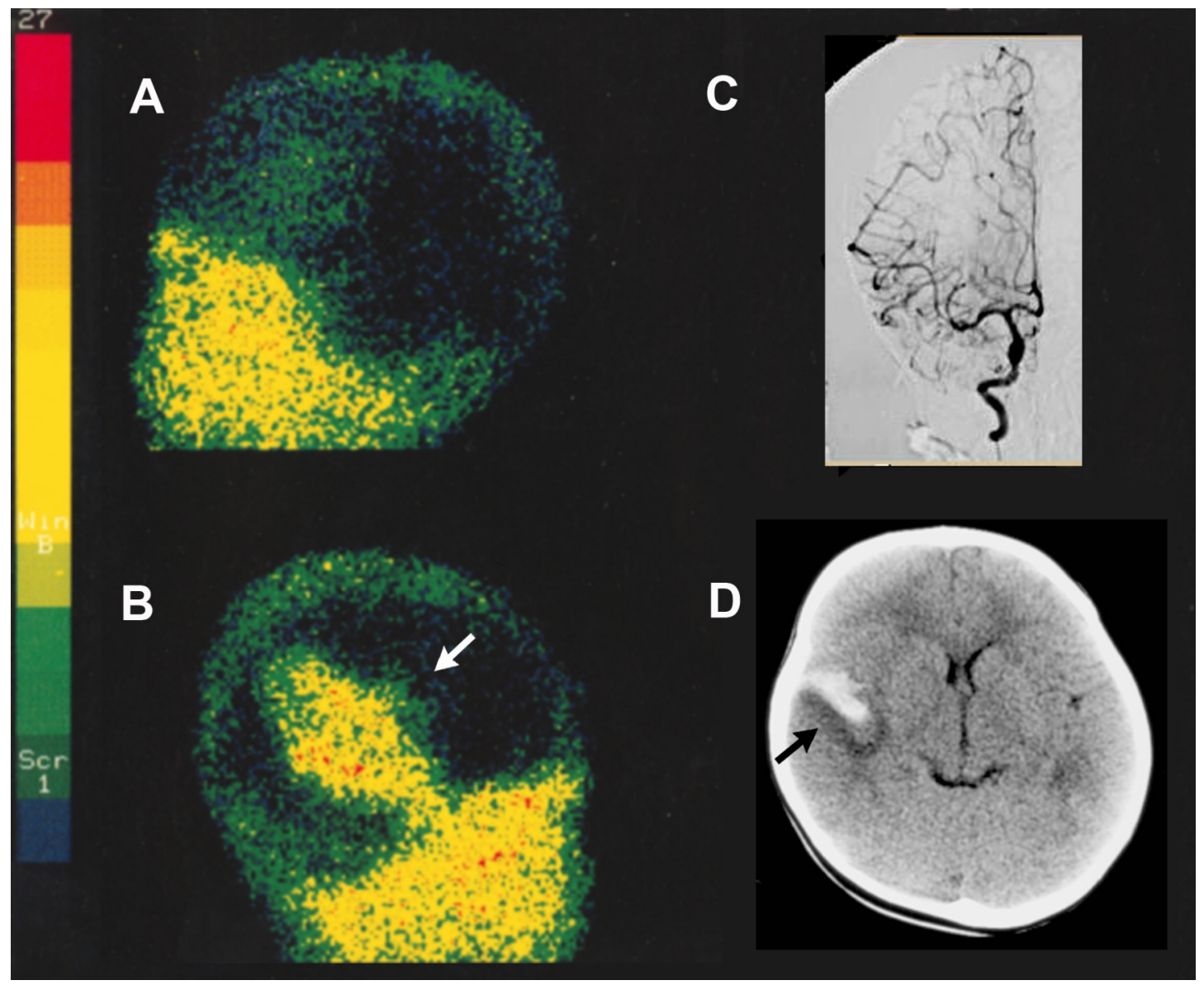

Fig. (2). Herpes simplex encephalitis involving the right temporal lobe. (A \& B) single photonon emission computed tomography (SPECT) brain scan showing increased tracer $\left({ }^{99 \mathrm{~m}} \mathrm{Tc}\right.$-DTPA) uptake in the right-temporal lobe (arrow in B), and no evidence of blood brain barrier breakdown in the left side (A). (C) Right carotid angiography (done for suspected arteriovenous malformation) revealed no vascular abnormality. (D) Axial non-contrast-enhanced CT brain revealed right temporal hyperdense area surrounded by hypodensity (arrow), representing acute hemorrhagic lesion.

supporting care. There was no statistically significant difference between the poor (moderate or severe sequelae) and good (minor or no sequelae) outcome groups with regards to the duration of therapy ( $\leq 14$ days $v s 21$ days). However, the difference was highly significant regarding the initiation of acyclovir treatment, either early ( $\leq 3$ days) or later $(\mathrm{p}=0.002)$. All patients with good outcome received acyclovir within 3 days from the start of symptoms while $71 \%$ of patients with poor outcome received treatment late (with delays for up to 25 days).

\section{DISCUSSION}

The clinical spectrum of the disease in our patients was in accordance with that reported in the literature $[3,22]$ Fever (present in all cases), seizures (in 73\%), disturbed sensorium (irritability and drowsiness), and focal neurologic features (hemiparesis, $6^{\text {th }}$ cranial nerve palsy and aphasia) were the main features. The lack of pathognomonic clinical presentation of HSE and similarities with those of encephalitis due to other viruses, metabolic encephalopathy (including mitochondrial disease) and stroke could explain the initial delayed diagnosis of some patients in the present cohort at their primary care centers $[23,24]$.
Although typical laboratory results are highly suggestive of HSV (CSF pleocytosis, the presence of RBCs and elevated protein levels, the absence of these features does not rule out a diagnosis of $\operatorname{HSE}[9,10]$. In the present study, $8(38 \%)$ of the $21 \mathrm{CSF}$ samples drawn between days 1 and 5 of illness showed $<10 \mathrm{WBC} / \mu \mathrm{l}$. It's noteworthy that although CSF pleocytosis is usually present in about $97 \%$ of cases [17], it may be absent in either immunocompetent [9, 25] or immunocompromised patients [26]. Also the presence of $\mathrm{RBC}$, following a non-traumatic lumbar puncture, is encountered with similar frequency in patients with encephalitis due to other causes [17].

Six $(50 \%)$ cases had negative CSF PCR, despite other evidence suggestive of HSV infection, which conforms with previous reports that a single negative PCR result does not exclude HSV as a cause of acute encephalitis [3, 8, 9, 27]. Also, one patient showed negative results on day 3 but positive results on repeated CSF testing on day 8 of his illness. This also consolidates previous observations that initial negative PCR results obtained within the first 3 days of illness may become positive on a subsequent CSF specimen, and should not interrupt antiviral therapy $[6,8,10$, $16,27]$. False negative results could be due to the absence of $\mathrm{HSV}$ or the presence of a very low viral load in the CSF at 

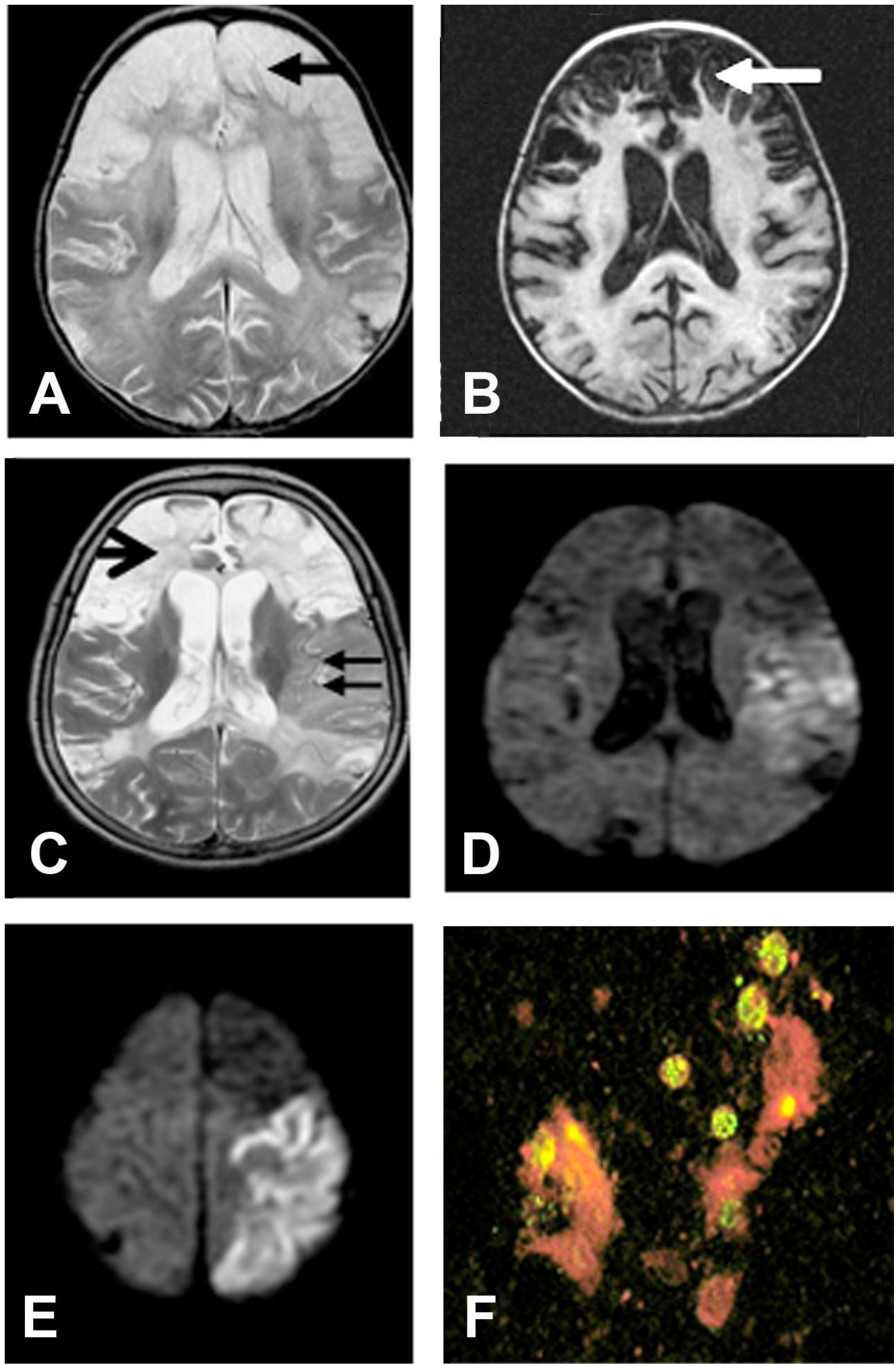

Fig. (3). MRI brain scans of Patient 2 (Tables 2 and 3). (A) Axial T2-weighted image (T2WI), (B) axial FLAIR sequence for study dated 1999 and (C) axial T2WI for study dated 2004, showing bifrontal cystic encephalomalacia (single arrows) and (A) diffuse white matter high signal intensity. (C) Shows high signal left temporal swollen cortex (double arrows). (D \& E) Axial diffusion images for the $2^{\text {nd }}$ study shows high signal (diffusion restriction) at the left temporo-parietal region indicating recent recurrent infection. (F) A swab from lip vesicular lesions in this patient, during relapse in 2004, revealed positive immunofluorescence for herpes simplex virus type 1 .

the onset acute encephalitis in children $[6,8,10]$. Other causes of false-negative HSV PCR results include the presence of porphyrin compounds in CSF derived from the degradation of haeme in erythrocytes [28]. Hence, caution should be used in interpreting negative PCR results in bloody CSF specimens. 
Table 1. Initial Presenting Symptoms and Signs in 18 Children with Herpes Simplex Encephalitis

\begin{tabular}{|c|c|c|c|c|}
\hline Symptoms and Signs & 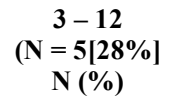 & $\begin{array}{c}13-48 \\
(N=9[50 \%]) \\
N(\%)\end{array}$ & $\begin{array}{c}\geq 49 \\
(\mathrm{~N}=4[22 \%]) \\
\mathrm{N}(\%)\end{array}$ & $\begin{array}{c}\text { Total } \\
(\mathrm{N}=\mathbf{1 8}[\mathbf{1 0 0} \%]) \\
\mathrm{N}(\%)\end{array}$ \\
\hline Fever & $5(100)$ & $9(100)$ & $4(100)$ & $18(100)$ \\
\hline Seizures & $3(60)$ & $3(33)$ & $4(100)$ & $13(72)$ \\
\hline Weakness/hemiparesis & $2(40)$ & $3(33)$ & $2(50)$ & $7(39)$ \\
\hline Drowsiness & $2(40)$ & $6(67)$ & $1(25)$ & $6(33)$ \\
\hline Headache & $0(0)$ & $2(22)$ & $4(100)$ & $6(33)$ \\
\hline Squint & $0(0)$ & $0(0)$ & $1(25)$ & $1(5.6)$ \\
\hline
\end{tabular}

Table 2. Features of 3 Relapsing Cases of Herpes Simplex Encephalitis During Initial Infection

\begin{tabular}{|c|c|c|c|c|c|c|c|c|c|c|c|c|c|c|}
\hline \multirow{2}{*}{$\begin{array}{c}\text { Patient } \\
\text { No }\end{array}$} & \multirow{2}{*}{\multicolumn{2}{|c|}{ Age Gender }} & \multicolumn{2}{|c|}{$\begin{array}{c}\text { Clinical } \\
\text { Manifestations } \\
\text { (Time After } \\
\text { Admission) }\end{array}$} & \multicolumn{4}{|c|}{ CSF Findings } & \multirow{2}{*}{$\begin{array}{c}\text { Serology } \\
\text { for HSV } \\
\text { (Types } \\
\text { I, and II) } \\
\text { Other } \\
\text { Virology } \\
\text { Investigations } \\
\text { (d)* }\end{array}$} & \multirow{2}{*}{$\begin{array}{c}\text { EEG } \\
\text { Findings }\end{array}$} & \multirow{2}{*}{$\begin{array}{l}\text { Imaging } \\
\text { Findings }\end{array}$} & \multirow{2}{*}{$\begin{array}{l}\text { SPECT } \\
\text { (Days } \\
\text { from } \\
\text { Clinical } \\
\text { Onset, } \\
\text { Reagent } \\
\text { Used) }\end{array}$} & \multirow{2}{*}{$\begin{array}{c}\text { Duration } \\
\text { of } \\
\text { Acyclovir } \\
\text { Treatment }\end{array}$} & \multirow{2}{*}{$\begin{array}{c}\text { Outcome } \\
\text { (Follow-Up } \\
\text { Period) }\end{array}$} \\
\hline & & & General & CNS & $\begin{array}{c}\text { WBC } \\
\text { Count } \\
\mathrm{X10}^{6} / \mathrm{L}\end{array}$ & $\begin{array}{c}\mathrm{RBC} \\
\mathbf{X 1 0}^{6} / \mathrm{L}\end{array}$ & $\begin{array}{c}\text { Protein } \\
\text { Level } \\
\text { g/L }\end{array}$ & $\begin{array}{l}\text { PCR } \\
\text { (d)* }\end{array}$ & & & & & & \\
\hline 1 & $2 y$ & Female & $\begin{array}{l}\text { Fever, } \\
\text { headache }\end{array}$ & $\begin{array}{l}\text { Drowsiness, } \\
\text { seizures, L } \\
\text { hemiparesis }\end{array}$ & & 29 & 0.27 & ND & $\begin{array}{l}1 \mathrm{gM}(+\mathrm{ve}) \\
1 \mathrm{gG}(+\mathrm{ve})\end{array}$ & $\begin{array}{l}\text { Diffuse } \\
\text { slowing, } \\
\text { L PLEDs }\end{array}$ & $\begin{array}{l}\text { MRI: T2W } \\
\text { hyperintensity } \\
\text { involving L } \\
\text { temporal lobe }\end{array}$ & ND & $10 \mathrm{~d}$ & Well (7d) \\
\hline 2 & $\begin{array}{l}20 \\
\text { mo }\end{array}$ & Male & $\begin{array}{l}\text { Fever, } \\
\text { irrita- } \\
\text { bility, } \\
\text { vomiting, } \\
\text { diarrhoea }\end{array}$ & $\begin{array}{l}\text { Chroeoform } \\
\text { movements } \\
\text { (3d) }\end{array}$ & & 0 & 0.39 & $\begin{array}{l}-\mathrm{ve} \\
(40 \\
\text { d) }\end{array}$ & $\begin{array}{l}\operatorname{lgM} \\
(-\mathrm{ve}, 3 \mathrm{~d}), \\
1 \mathrm{gG}(-\mathrm{ve}, 3 \mathrm{~d})\end{array}$ & $\begin{array}{l}\text { Diffuse } \\
\text { slowing, } \\
\text { persistent } \\
\text { spike } \\
\text { focus } \\
\text { in } \\
\mathrm{R} \text { frontal } \\
\text { region }\end{array}$ & $\begin{array}{l}\text { MRI } \\
\text { (Fig. 3A: } \\
\text { Bifrontal } \\
\text { cystic } \\
\text { encephalomacia } \\
\text { and } \\
\text { diffuse } \\
\text { white } \\
\text { matter } \\
\text { attenuation } \\
\text { on } \\
\text { T2W } \\
\text { image }\end{array}$ & ND & $21 d$ & $\begin{array}{l}\text { Seizures } \\
\text { (controlled), } \\
\text { global } \\
\text { development } \\
\text { delay, } \\
\text { mixed } \\
\text { type } \\
\text { of } \\
\text { cerebral } \\
\text { palsy } \\
(66 \mathrm{mo})\end{array}$ \\
\hline 3 & $4 y$ & Female & $\begin{array}{l}\text { Vomiting, } \\
\text { cough, } \\
\text { decreased } \\
\text { activity, } \\
\text { irritability }\end{array}$ & $\begin{array}{l}\text { Drowsiness, } \\
\text { decreased } \\
\text { LOC, } \\
\text { seizures, } \\
\text { R } \\
\text { hemiparesis }\end{array}$ & & 330 & 0.12 & $\begin{array}{l}+\mathrm{ve} \\
(6 \mathrm{~d})\end{array}$ & ND & $\begin{array}{l}\text { Diffuse } \\
\text { slowing, } \\
(\mathrm{L}>\mathrm{R})\end{array}$ & $\begin{array}{l}\text { MRI: High } \\
\text { signal } \\
\text { swollen } \\
\text { gyri of } \\
\text { the left } \\
\text { temporo- } \\
\text { parieto- } \\
\text { occipital } \\
\text { region } \\
\text { on T2W }\end{array}$ & $\begin{array}{l}\text { Increased } \\
\text { tracer uptake in } \\
\text { L frontal, } \\
\text { L } \\
\text { temporopariental } \\
\text { lobes, } \\
\text { extending } \\
\text { to L occipital } \\
\text { lobe } \\
\text { (6d, } \\
\text { HMPAO) }\end{array}$ & $21 \mathrm{~d}$ & $\begin{array}{l}\text { Seizures } \\
\text { (Controlled, } \\
20 \mathrm{mo})\end{array}$ \\
\hline
\end{tabular}

$\mathrm{CNC}=$ central nervous system $; \mathrm{d}=$ days; $\mathrm{EEG}=$ electroencephalogram $; \mathrm{HMPAO}=$ technetium- $99 \mathrm{~m}$-hexamethyl propyleneamine oxime; $\mathrm{HSV}=$ herpes simplex virus; $\mathrm{L}=$ left $; \mathrm{LOC}=$

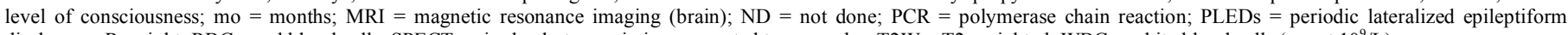
discharges; $\mathrm{R}=$ right; $\mathrm{RBC}=$ red blood cells; $\mathrm{SPECT}=$ single photon emission computed tomography; $\mathrm{T} 2 \mathrm{~W}=\mathrm{T} 2$-weighted; $\mathrm{WBC}=$ white blood cells $\left(\right.$ count $\left.10^{9} / \mathrm{L}\right) ; \mathrm{y}=\mathrm{years}$. 
Table 3. Features of 3 Cases of Herpes Simplex Encephalitis During Relapse

\begin{tabular}{|c|c|c|c|c|c|c|c|c|c|c|c|c|c|}
\hline \multirow[t]{2}{*}{$\begin{array}{c}\text { Patient } \\
\text { No }\end{array}$} & \multirow[t]{2}{*}{ Age Gender } & \multicolumn{2}{|c|}{$\begin{array}{c}\text { Clinical } \\
\text { Manifestations } \\
\text { (Time } \\
\text { After } \\
\text { Admission) }\end{array}$} & \multicolumn{4}{|c|}{$\begin{array}{c}\text { CSF } \\
\text { Findings }\end{array}$} & \multirow{2}{*}{$\begin{array}{c}\text { Serology for } \\
\text { HSV } \\
\text { (Types I, } \\
\text { and II) } \\
\text { Other } \\
\text { Virology } \\
\text { Investigations } \\
\text { (d)* }\end{array}$} & \multirow{2}{*}{$\begin{array}{c}\text { EEG } \\
\text { Findings }\end{array}$} & \multirow[t]{2}{*}{$\begin{array}{l}\text { Imaging } \\
\text { Findings }\end{array}$} & \multirow{2}{*}{$\begin{array}{l}\text { SPECT } \\
\text { (Days } \\
\text { from } \\
\text { Clinical } \\
\text { Onset, } \\
\text { Reagent } \\
\text { Used) }\end{array}$} & \multirow{2}{*}{$\begin{array}{c}\text { Duration } \\
\text { of } \\
\text { Acyclovir } \\
\text { Treatment }\end{array}$} & \multirow{2}{*}{$\begin{array}{c}\text { Outcome } \\
\text { (Follow-Up } \\
\text { Period) }\end{array}$} \\
\hline & & General & CNS & $\begin{array}{c}\text { WBC } \\
\text { Count } \\
{\mathrm{X} 10^{6} / \mathrm{L}}^{2}\end{array}$ & $\begin{array}{l}\text { RBC } \\
\text { Count } \\
{\mathrm{X} 10^{6} / \mathrm{L}}^{2}\end{array}$ & $\begin{array}{c}\text { Protein } \\
\text { Level } \\
\text { g/L }\end{array}$ & $\begin{array}{l}\text { PCR I } \\
\text { (d)* }\end{array}$ & & & & & & \\
\hline 1 & $2 y$ & $\begin{array}{l}\text { Fever, } \\
\text { irritability }\end{array}$ & $\begin{array}{l}\text { Chroeoform } \\
\text { movements }\end{array}$ & & 12,500 & 2.02 & ND 1 & ND & ND & $\begin{array}{l}\text { MRI : Focal } \\
\text { cystic } \\
\text { encephalomalacia } \\
\text { in } L \text { temporal } \\
\text { lobe. Evidence of } \\
\text { recent infection } \\
\text { (oedema) in } R \\
\text { temporal lobe }\end{array}$ & $\begin{array}{l}\text { Decreased } \\
\text { regional CBF } \\
\text { a in L } \\
\text { temporo- } \\
\text { parietal } \\
\text { region (96d, } \\
\text { HMPAO) }\end{array}$ & $21 \mathrm{~d}$ & $\begin{array}{l}\text { Seizures, } \\
\text { delayed } \\
\text { language } \\
\text { development } \\
(4 y)\end{array}$ \\
\hline 2 & $\begin{array}{l}7 y \\
2 \\
\text { mo }\end{array}$ & $\begin{array}{l}\text { Lip } \\
\text { vesicular } \\
\text { lesions } \\
\text { (Fig. 3), } \\
\text { fever, } \\
\text { symptoms } \\
\text { of URTI, } \\
\text { vomiting }\end{array}$ & $\begin{array}{l}\text { Seizures, } \\
\text { decreased } \\
\text { LOC, R } \\
\text { hemisparesi } \\
\text { choreoform } \\
\text { movements } \\
(2 \mathrm{w})\end{array}$ & $\begin{array}{l}110 \\
0\end{array}$ & $\begin{array}{l}120 \\
0\end{array}$ & $\begin{array}{l}0.53 \\
0.20\end{array}$ & $\begin{array}{l}+v e+ \\
(3 \mathrm{~d}) \mathrm{r} \\
-\mathrm{ve} \\
\left(12 \mathrm{~d}_{\mathrm{f}}^{\mathrm{f}}\right. \\
\mathrm{I}\end{array}$ & $\begin{array}{l}+\mathrm{ve} \\
\text { RSV(NPA) } \\
\text { Swab from lip } \\
\text { vesicles +ve } \\
\text { for HSV type } \\
\text { I (Fig. 3) }\end{array}$ & $\begin{array}{l}\text { Diffuse } \\
\text { slowing, } \\
\text { frequent } \mathrm{R} \\
\text { fronto- } \\
\text { temporal } \\
\text { epileptiform } \\
\text { discharges }\end{array}$ & $\begin{array}{l}\text { MRI } \\
\text { (Fig. 3B, } \\
\text { C \& D): High } \\
\text { signal } \\
\text { swollen L } \\
\text { temporal } \\
\text { cortex on } \\
\text { T2W image, } \\
\text { high signal } \\
\text { (diffusion } \\
\text { restriction) } \\
\text { at L } \\
\text { temporoparietal } \\
\text { region }\end{array}$ & $\begin{array}{l}\text { Bilateral } \\
\text { poor } \\
\text { perfusion of } \\
\text { both frontal } \\
\text { lobes and } \\
\text { both parietal } \\
\text { lobes (L } \\
\text { more } \\
\text { affected than } \\
\text { R, high } \\
\text { perfusion in } \\
\text { L temporal } \\
\text { lobe (6d, } \\
\text { HMPAO) }\end{array}$ & $21 \mathrm{~d}$ & $\begin{array}{l}\text { Seizures, } \\
\text { global } \\
\text { developmental } \\
\text { delay, mixed } \\
\text { type of } \\
\text { cerebral palsy } \\
\left(1 \frac{1}{2} \text { y) }\right.\end{array}$ \\
\hline 3 & $\begin{array}{l}5 y \\
10 \\
\text { mo }\end{array}$ & Fever & $\begin{array}{l}\text { Drowsiness, } \\
\text { L } \\
\text { hemiparesis, } \\
\text { L } 6^{\text {th }} \text { cranial } \\
\text { nerve palsy }\end{array}$ & 100 & 128 & 1.28 & $\begin{array}{l}\text {-ve } \quad ~ \\
\text { (1d) }\end{array}$ & ND & $\begin{array}{l}\text { Diffuse } \\
\text { slowing, } \\
(\mathrm{R}>\mathrm{L}) \text {, } \\
\text { continuous } \\
\text { theta-delta } \\
\text { activity } \\
\text { with clear } \\
\text { asymmetry } \\
(\mathrm{R}>\mathrm{L})\end{array}$ & $\begin{array}{l}\text { CT:Normal. } \\
\text { MRI: atropic } \\
\text { changes in L } \\
\text { temporo-parietal } \\
\text { lobes, T2W } \\
\text { hyperintensity } \\
\text { and swollen gyri } \\
\text { of R parietal lobe }\end{array}$ & $\begin{array}{l}\text { Increased } \\
\text { tracer } \\
\text { concentration } \\
\text { in } \mathrm{R} \\
\text { temporal } \\
\text { lobe }(4 \mathrm{~d} \text {, } \\
\text { DTPA). } \\
\text { Decreased } \\
\text { tracer uptake } \\
\text { in } \mathrm{R} \\
\text { temporal and } \\
\text { parital lobes } \\
\text { (25d, } \\
\text { HMPAO) }\end{array}$ & $21 \mathrm{~d}$ & Well (16 mo) \\
\hline
\end{tabular}

*Days from clinical onset.

$\mathrm{CNC}=$ central nervous system; $\mathrm{CT}=$ computed tomography (brain); $\mathrm{d}=$ days; DTPA-technitium-99m-diethylenetriaminepentaacetic acid; EEG = electroencephalogram; HMPAO = technetium-99m-hexamethyl propyleneamine oxime; HSV-herpes simplex virus; L = left; LOC = level of consciousness; mo = months; MRI = magnetic resonance imaging (brain); ND $=$ not done; NPA-nasopharyngeal aspirate; $\mathrm{PCR}=$ polymerase chain reaction; $\mathrm{R}=$ right; $\mathrm{RBC}=$ red blood cells; $\mathrm{RSV}=$ respiratory synctial virus; $\mathrm{SPECT}=$ single $\mathrm{photon}$ emission computed tomography; $\mathrm{T} 2 \mathrm{~W}=\mathrm{T} 2$-weighted; URTI $=$ upper respiratory tract infection; $\mathrm{w}=$ weeks; $\mathrm{WBC}=$ white blood cells; $\mathrm{y}=$ years

In the present study, neuroimaging had significant impact as diagnostic tools. Cranial CT Scan was done for 14 patients, while 11 patients were evaluated with MRI. But because our patients did only CT, only MRI, neither or both at different times of the disease course, we were unable to compare the sensitivity of these modalities for diagnosis. However, initial CT scans done on days 1-8 from onset of symptoms were normal in $5(50 \%)$ of 10 patients, compared to one $(9 \%)$ of eleven MRI scans done during the acute stage. Our results are in agreement with other studies which confirmed the superiority of MRI, as neuro-imaging modality, for detecting lesions of $\operatorname{HSE}[8,10,29]$. In the present study abnormalities were mainly confined to the temporal lobes $(73 \%)$ but could also be seen in other regions, similar the experiences of others [8, 10]. Extra temporal (including cortical and subcortical) regions are detected in $40 \%$ of children but only in $9-15 \%$ of adult patients [3]. On the other hand, diffuse white matter involvement was seen in a child (Patient 2, Table 2; Fig. 3A) who developed choreoathetoid movements while he was on antiviral therapy. Such evolution of HSE has been well described [30], and is considered to be due to the occurrence of post infectious immune-mediated encephalitis [3, 27, 31]. Also in agreement with previous studies indicating that HSE in children and adults is commonly hemorrhagic [31-33], we found hyperdense lesions of hemorrhage in $60 \%$ of cranial CT scans of our patients. 
In the present study, all patients showed abnormalities on EEG tracings and $6(35 \%)$ displayed PLEDs. In a recent study by Elbers and associates [10], PLEDs were found in $2(13 \%)$ patients whereas an earlier study on adult HSE showed that these periodic complexes had sensitivity of $81 \%$ and specificity of 59\% [17]. Although PLEDs are seen in other cerebral disorders $[34,35]$, their presence in the setting of a rapidly progressive neurological disease associated with fever is strongly indicative of HSV-1 encephalitis [22].

Although treatment with acyclovir significantly improves the outcome of HSE, the reported mortality rate in patients treated with acyclovir ranged between $0 \%$ and $10 \%$ in children compared to nearly $20 \%$ in adults [3, 36-38]. There were no deaths in our cohort but 5 (28\%) patients experienced severe neurologic sequelae in the form of intractable seizures, mental retardation and/or residual cerebral palsy; and 3 patients relapsed. Two (11\%) patients had moderate sequelae consisting of easily controlled seizures or ADHD. In earlier reports the rates of moderate sequelae ranged from $25 \%$ to $36 \%$ and of severe neurological disabilities from 0 to $100 \%[37,39]$, compared to $30 \%-31 \%$ and $5 \%$ to $31 \%$, respectively, in the more recent studies $[10,40]$. These varied proportions reflect differences in evaluation criteria and duration of follow-up.

Similar to the experiences of others [40, 41], no significant difference was noted in the outcome with the different durations of treatment given. Patients who recover without sequelae of HSE, even with no antiviral therapy, have been reported [41] and they are thought to constitute the group of patients who are only mildly infected [40]. However, in two studies [36, 42], the duration of treatment and total dosage of acyclovir given were significantly less in children with early HSE relapse than in the non-recurrent group. Conversely, all eleven patients with good outcome in the present study received acyclovir within 3 days from start of symptoms while $5(71 \%)$ of the 7 patients with poor outcome were delayed in diagnosis and treatment $(\mathrm{P}=$ 0.002). Delayed initiation of acyclovir therapy is a known poor prognostic factor $[40,43]$. Hence, since in the early beginnings of illness the outcome of patients with HSE cannot be predicted, and because of the disastrous effects of delayed treatment, early diagnosis and proper acyclovir initiation are vital for proper management [3, 22, 27, 40].

In children, recurrence or relapse of HSE occurs in 5$26 \%$ of acyclovir - treated patients $[9,42]$. The pathogenesis of this condition is poorly defined, but persistent herpes simplex virus replication, reactivation, or immune-mediated mechanisms may play a role $[3,44]$. The CSF may be negative for HSV by PCR [44]. However, the presence of a positive CSF PCR, as seen in Patient 2 (Table 3), suggests that relapse is due to persistent viral infection rather than a post-infections immune-mediated process [27]. Patient 1 (Table 2) in the present study, who experienced a relapse 18 days after first HSE episode, has been treated initially with a 10 -day course of acyclovir. This may conform to previous observations that a 21-day course of acyclovir is more effective in reducing the risk of recurrence associated with HSE $[3,10,30]$. It's noteworthy that in the past decade, the standard care became an increase in the duration of treatment from 14 days to 21 days [45]. However, the other two relapsing children (patients 2 and 3, Table 2) had the full 21- day course of acyclovir during their initial admissions to KKUH. They relapsed after periods of 66 months and 22 months, respectively. Patient 3 (Table 2) had her sister afflicted with HSE and is enrolled in the present study. Taken together, these observations may point to an underlying genetic susceptibility. Several studies have appeared recently unraveling the genetic basis of HSE [4648]. They proved that, at least in some of children, HSE results from a series of autosomal recessively (AR) inherited monogenic primary immunodeficiencies that impair the TLR3- and UNC-93B-dependent-production of interferon (INF) [Alpha/beta] and IFN (lambda) in the central nervous system. Given the impact of AR inheritance in the pathogenesis of pediatric neurologic diseases in this region [49], studies are underway to investigate, in a collaborative research, this genetic susceptibility in our cohort of patients, as well as, in children admitted with HSE after the present study period.

\section{ACKNOWLEDGEMENTS}

The authors wish to thank Dr. Gaafar A. Mustafa for the diligent patient care and Dr. Manal Abbo for data retrieval. Thanks are also due to Ms. Rowena Fajardo and Ms. Loida M. Sese for secretarial assistance.

\section{REFERENCES}

[1] Whitley RJ, Kimberlin DW. Herpes simplex encephalitis: children and adolescents. Semin Pediatr Infect Dis 2005; 16:17-23.

[2] Whitley RJ, Lakeman F. Herpes simplex virus infections of the central nervous system: therapeutic and diagnostic considerations. Clin Infect Dis 1995; 20: 414-20.

[3] De Tiege X, Rozenberg F, Heron B. The spectrum of herpes simplex encephalitis in children. Eur J Paediatr Neurol 2008; 12: 72-81.

[4] Raschilas F, Wolff M, Delatour F, et al. Outcome of and prognostic factors for herpes simplex encephalitis in adult patients: results of a multi-center study. Clin Infect Dis 2002; 35: 254-60.

[5] Lakeman FD, Whitley RJ. National institute of allergy and infectious diseases collaborative antiviral study group. Diagnosis of herpes simplex encephalitis: application of polymerase chain reaction to cerebrospinal fluid from brain-biopsied patients and correlation with disease. J Infect Dis 1995; 171: 857-63.

[6] Weil AA, Glaser CA, Amad Z, Forghani B. Patients with suspected herpes simplex encephalitis: rethinking an initial negative polymerase chain reaction result. Clin Infect Dis 2002; 34: 1154-7.

[7] Atkins JT. HSV PCR for CNS infection: pearls and pitfalls. Pediatr Infect Dis J 1999; 18: 823-4.

[8] De Tiege X, Heron B, Lebon P, Ponsot G, Rozenberg F. Limits of early diagnosis of herpes simplex encephalitis in children: a retrospective study of 38 cases. Clin Infect Dis 2003; 36: 1335-9.

[9] De Tiege X, Rozenberg F, Burlot K, Gaudelus J, Ponsot G, Heron B. Herpes simplex encephalitis: diagnostic problems and late relapse. Dev Med Child Neurol 2006; 48: 60-3.

[10] Elbers JM, Bitnum A, Richardson SE, et al. A 12-year prospective study of childhood herpes simplex encephalitis: Is there a broader spectrum of disease? Pediatrics 2007; 119: e399-407.

[11] Paillard C, Vanhulle C, Devaux AM, Ensel P, Monroc-Morval M, Blanc T. Recurrence of herpes simplex encephalitis. Arch Pediatr 1999; 6: 1081-5.

[12] Wolf RW, Schultze D, Fretz C, Weissert M, Waibel P. Atypical herpes simplex encephalitis presenting as operculum syndrome. Pediatr Radiol 1999; 29: 191-3.

[13] Leonard JR, Moran CJ, Cross DT III, Wippold FJ II, Schlesinger Y, Storch G. MR imaging of herpes simplex type I encephalitis in infants and young children: a separate pattern of findings. AJR Am J Roentgenol 2000; 174: 1651-65.

[14] Schroth G, Gawehn J, Thorn A, Vallbracht A, Voigt K. Early diagnosis of herpes simplex encephalitis by MRI. Neurology 1987; 37: 179-83. 
[15] Hatipoglu HG, Sakmar B, Yuksel E. Magnetic resonance and diffusion-weighted imaging findings of herpes simplex encephalitis. Herpes 2008; 15: 13-7.

[16] Akyldz BN, Gumus H, Kumandas S, Coskun A, Karakukucu M, Yklmaz A. Diffusion-weighted magnetic resonance is better than polymerase chain reaction for early diagnosis of herpes simplex encephalitis: a case report. Pediatr Emerg Care 2008; 24: 377-9.

[17] Whitley RJ, Soong SJ, Linneman C, Liu C, Pazin G, Alford CA. NIAID Collaborative Antiviral Study Group. Herpes simplex encephalitis: clinical assessment. JAMA 1982; 247: 317-20.

[18] Smith JB, Westmoreland BF, Reagan TJ, Sandok BA. A distinctive clinical EEG profile in herpes simplex encephalitis. Mayo Clin Proc 1975; 50: 469-74.

[19] Laures J, Nikkinen P, Lindroth L, Brownell A, Liewebdahl K, Iievanainen M. Diagnosis of acute herpes simplex encephalitis by brain perfusion single photon emission computed tomography. Lancet 1988; 2: 1188-91.

[20] Bulakbasi N, Kocaoglu M. Central nervous system infections of herpes virus family. Neuroimaging Clin N Am 2008; 18: 53-84.

[21] Whitley RJ, Cobbs CG, Alford CA Jr, et al. Diseases that mimic herpes simplex encephalitis. Diagnosis, presentation and outcome. NIAD collaborative antiviral study group. JAMA 1989; 262: 234-9.

[22] Gilden DH, Mahalingam R, Cohrs RJ, Tyler KL. Herpes virus infections of the nervous system. Nat Clin Pract Neurol 2007; 3: 82-94.

[23] Baringer JR. Herpes simplex virus encephalitis. In: Davis LE, Kennedy PGE, Eds. Infectious diseases of the nervous system. Oxford: Butterworth-Heinemann 2000; pp. 139-64.

[24] Shellhaas RA, Smith SE, O'Tool E, Licht DJ, Ichord RN. Mimics of childhood stroke: Characteristics of a prospective cohort. Pediatrics 2006; 118: 704-9.

[25] Schlageter N, Jubelt B, Vick NA. Herpes simplex encephalitis without CSF leukocytosis. Arch Neurol 1984; 41: 1007-8.

[26] Tan SV, Guiloff RJ, Scaravilli F, Klapper PE, Cleator GM, Gazzard BG. Herpes simplex type 1 encephalitis in acquired immunodeficiency syndrome. Ann Neurol 1993; 34: 619-22.

[27] Tyler KL. Herpes simplex virus infections of the central nervous system: encephalitis and meningitis, including Mollarets's. Herpes 2004; 11(Suppl 2): 57A-564A.

[28] Aurelius E, Johansson B, Skoldenberg B, Staland A, Forsgren M. Rapid diagnosis of herpes simplex encephalitis by nested polymerase chain reaction assay of cerebrospinal fluid. Lancet 1991; 337: 189-92.

[29] Domingues RB, Fink MC, Tsanaelis AM, et al. Diagnosis of herpes simplex encephalitis by magnetic resonance imaging and polymerase chain reaction assay of cerebrospinal fluid. J Neurol Sci 1998; 157: 148-53.

[30] Gascon GG, al Jarallah AA, Okamoto E, al Ahdal M, Kessie G, Frayha H. Chorea as a presentation of herpes simplex encephalitis relapse. Brain Dev 1993; 15: 178-81.

[31] De Tiege X, Rozenberg F, Des Portes VB, et al. Herpes simplex encephalitis relapses in children: differentiation of two neurologic entities. Neurology 2003; 61: 241-3.
[32] Becker LE. Infections of the developing brain. Am J Neurol 1992; 13: 537-9.

[33] Jordan J, Enzman DR. Encephalitis. Neuroimaging Clin N Am 1991; 35: 17-38.

[34] Chen KS, Kuo MF, Wang HS, Huang SC. Periodic lateralized epileptiform discharges of pediatric patients in Taiwan. Pediatr Neurol 2003; 28: 100-03.

[35] Dan YF, Pan ABS, Lim SH. Periodic lateralized epileptiform discharges: Aetiology and association with EEG seizures. Neurol Asia 2004; 9(Suppl 1): 107-8.

[36] Kimura H, Aso K, Kuzushima K, Hanada N, Shibata M, Morishima T. Relapse of herpes simplex encephalitis in children. Pediatrics 1992; 89: 891-4.

[37] Lahat E, Barr J, Barkai G, Paret G, Brand N, Barzilai A. Long term neurological outcome of herpes encephalitis. Arch Dis Child 1999; 80: 69-71.

[38] Whitley RJ, Alford CA, Hirsch MS, et al. Vidarabine versus acyclovir therapy in herpes simplex encephalitis. N Engl J Med 1986; 314: 144-9.

[39] Cameron PD, Wallace SJ, Munro J. Herpes simplex virus encephalitis: problems in diagnosis. Dev Med Child Neurol 1992; 34: 134-40.

[40] Hsieh WB, Chiu NC, Hu KC, Ho CS, Huang FY. Outcome of herpes simplex encephalitis in children. $\mathrm{J}$ Microbiol Immunol Infect 2007; 40: 34-8.

[41] Marton R, Gotlieb-Steimatsky T, Klein C, Lahat E, Arlazoroff A. Mild form of acute herpes simplex encephalitis in childhood. Brain Dev 1995; 17: 360-1.

[42] Ito Y, Kimura H, Yabuta Y, et al. Exacerbation of herpes simplex encephalitis after successful treatment with acyclovir. Clin Infect Dis 2000; 30: 185-7

[43] McGrath N, Anderson NE, Croxson MC, Powel KF. Herpes simplex encephalitis treated with acyclovir: diagnosis and long term outcome. J Neurol Neurosurg Psychiatry 1997; 63: 321-6.

[44] De Tiege X, De Laet C, Mazoin N, et al. Post-infectious immunemediated encephalitis after pediatric herpes simplex encephalitis. Brain Dev 2005; 27: 304-7.

[45] Whitley RJ, Roizman B. Herpes simplex virus infections. Lancet 2001; 357: 1513-8.

[46] Bustamante J, Boisson-Dupuis S, Jouanguy E, et al. Novel primary immunodeficiencies revealed by the investigation of pediatric infectious diseases. Curr Opin Immunol 2008; 20: 39-48.

[47] Sancho-Shimizu V, Zhang SY, Abel L, et al. Genetic susceptibility to herpes simplex virus 1 encephalitis in mice and humans. Curr Opin Allergy Clin Immunol 2007; 7: 495-505.

[48] Zhang SY, Jouanguy E, Ugolini S, et al. TLR3 deficiency in patients with herpes simplex encephalitis. Science 2007; 317 1522-7.

[49] Salih M. Neuromuscular disorder among Arabs. In: Teebi A, Farag T, Eds. Genetic Disorders among Arab Populations. Oxford: Oxford University Press 1997: pp. 126-57. 